\title{
Solicitous use of injection remdesivir, tablet baricitinib, and plasma therapy for severe COVID-19 patient associated with Stage 4 sarcoidosis and type 2 diabetes mellitus: A case report
}

\author{
Megha Bajaj, Ashok K Saxena, Suman Choudhary, Sapna Jain \\ From Senior Resident, Department of Anaesthesiology and Critical Care, UCMS and Guru Teg Bahadur Hospital, New Delhi, India
}

\begin{abstract}
COVID-19 infection caused by single-stranded RNA virus was declared as a global pandemic by the WHO. Various concomitant diseases including diabetes, hypertension, and sarcoidosis increase mortality and morbidity in patients with COVID-19 infection. In this present case report, we effectively treated a severe COVID-19 patient with Stage 4 pulmonary sarcoidosis and type 2 diabetes mellitus who required intensive care unit using a multimodal approach including injection remdesivir, baricitinib, plasma therapy, graded oxygen therapy, and other supportive care.
\end{abstract}

Key words: COVID-19, Sarcoidosis, Remdesivir, Baricitinib, Diabetes mellitus

$\mathrm{S}$ evere acute respiratory syndrome coronavirus 2 (SARSCoV-2) is a single-stranded positive-sense RNA virus that was first identified in December 2019 in China. Till May 18, 2021, there have been 163,212,543 confirmed cases of COVID19, including 3,383,979 deaths as reported by the World Health Organization (WHO) [1]. In addition to diabetes, hypertension, and cardiovascular accident, the treatment of COVID-19 among patients with underlying interstitial lung disease (ILD) more specifically, sarcoidosis may include hospital admission, possible drug treatment, caution with steroids, and avoidance of mechanical ventilation in acute exacerbation of ILD [2]. Sarcoidosis is a chronic disease of unknown cause characterized by enlarged lymph nodes in various parts of the body and the widespread appearance of granulomas derived from reticuloendothelial cells. These granulomas become calcified and cause permanent damage to the lungs [3], which makes the patient more susceptible to infections including COVID-19. As COVID-19 evolves, it has become clear that the interplay between COVID-19 and diabetes has a complex pathophysiology. Not only COVID-19 outcomes are more severe in people with diabetes and metabolic dysfunction, but it could also precipitate metabolic complications such as diabetic ketoacidosis and hyperglycemia. Thus, making the management of COVID-19 more difficult [4].

Here, in this case report, we are presenting a case of a severe COVID-19 patient associated with Stage 4 pulmonary sarcoidosis

\section{Access this article online}

Received - 19 May 2021

Initial Review - 05 June 2021

Accepted - 29 June 2021

DOI: $10.32677 /$ IJCR.2021.v07.i07.013 with severe fibrosis and type 2 diabetes mellitus. However, on a search of the literature, we could not retrieve any case report for successful use of remdesivir, tablet baricitinib, and plasma therapy with good outcome during multimodal management of severe COVID-19 with sarcoidosis and diabetes mellitus in a patient of Asian origin.

\section{CASE REPORT}

A 58-year-old male was referred to the emergency department of our hospital, New Delhi, India, with chief complaints of cough for 5 days and fever for 4 days. The patient was positive for COVID19 on reverse transcription-polymerase chain reaction (RT-PCR) testing. He was a biopsy-proven known case of Stage 4 sarcoidosis diagnosed 5 years back and type 2 diabetes mellitus diagnosed 10 years back and was taking treatment for the same including tablet prednisolone $20 \mathrm{mg}$ once daily (OD), tablet $\mathrm{N}$-acetylcysteine $200 \mathrm{mg}$ twice daily (BD), and tablet metformin $500 \mathrm{mg}$ thrice daily.

On examination, the patient was conscious and well oriented with difficulty in breathing, with $\mathrm{SpO}_{2}$ only $80 \%$ on room air and $95 \%$ on high $\mathrm{FiO}_{2}$ mask, his respiratory rate was $24 / \mathrm{min}$, blood pressure was $132 / 88 \mathrm{mmHg}$, pulse rate of $84 / \mathrm{min}$, and blood sugar was $300 \mathrm{mg} / \mathrm{dL}$.

His hemogram, liver, and kidney function tests were within normal limits.

The treatment for COVID-19 was initiated which included prone positioning for $30-120 \mathrm{~min} 3$ times each day, tablet

\footnotetext{
Correspondence to: Dr. Megha Bajaj, Department of Anaesthesiology and Critical Care, UCMS and GTB Hospital, New Delhi, India. E-mail: meghabajaj2803@gmail.com

(C) 2021 Creative Commons Attribution-NonCommercial 4.0 International License (CC BY-NC-ND 4.0).
} 
ivermectin $12 \mathrm{mg}$ BD for 3 days, tablet doxycycline $100 \mathrm{mg}$ BD for 5 days, tablet Vitamin C $1000 \mathrm{mg}$ thrice daily, injection methylprednisolone $62.5 \mathrm{mg} \mathrm{BD}$, injection enoxaparin $0.6 \mathrm{ml}$ $\mathrm{BD}$, and tablet zinc $50 \mathrm{mg} \mathrm{OD}$ and the patient was shifted to the intensive care unit (ICU). Insulin infusion was started with 2 hourly sugar charting maintaining the blood sugar levels between 140 and $180 \mathrm{mg} / \mathrm{dL}$. Arterial blood gas (ABG) monitoring revealed a $\mathrm{PaO}_{2}: \mathrm{FiO}_{2}$ ratio of $300, \mathrm{pH}: 7.41, \mathrm{PaO}_{2}$ of $98 \mathrm{mmHg}$, $\mathrm{PaCO}_{2}$ of $35 \mathrm{mmHg}$, and basal energy expenditure of $2 \mathrm{mmol} / \mathrm{L}$. High-resolution computed tomography (CT) thorax impression was evident of CORAD-6 and bilateral ground-glass opacities/ consolidation with CT severity index $-21 / 25$.

On the $2^{\text {nd }}$ day, he was maintaining well on a high $\mathrm{FiO}_{2}$ non-rebreathing mask at a flow of $15 \mathrm{~L} / \mathrm{min}$ and occasionally also required a high-flow nasal cannula at $50 \mathrm{~L} / \mathrm{min}$. The same treatment was continued and $\mathrm{D}$-dimer and $\mathrm{C}$-reactive protein (CRP) values were $947 \mathrm{ng} / \mathrm{ml}$ and $72 \mathrm{mg} / \mathrm{dl}$, respectively. On the $5^{\text {th }}$ day, the patient's condition worsened, his $\mathrm{PaO}_{2}$ dropped to $74 \mathrm{mmHg}$, and $\mathrm{PaO}_{2}: \mathrm{FiO}_{2}$ ratio dropped to $180 \mathrm{mmHg}$. Subsequently, we switched over to bilevel positive airway pressure (BiPAP) support. D-dimer, CRP, S. ferritin, and interleukin-6 (IL-6) values were $1227 \mathrm{ng} / \mathrm{mL}, 110 \mathrm{mg} / \mathrm{dL}, 256 \mathrm{ng} / \mathrm{mL}$, and $35.7 \mathrm{pg} / \mathrm{mL}$, respectively. Now, the patient was administered injection remdesivir $200 \mathrm{mg}$ in $100 \mathrm{ml}$ of normal saline given over $1 \mathrm{~h}$, followed by $100 \mathrm{mg}$ in $100 \mathrm{ml}$ of normal saline, each day for 9 days. He was also administered tablet baricitinib $4 \mathrm{mg}$ OD for 14 days along with an injection of remdesivir.

On the $6^{\text {th }}$ day of admission, the patient was transfused one unit of plasma after cross-matching, and transfusion was repeated after $48 \mathrm{~h}$. Injection ceftriaxone $1 \mathrm{~g}$ twice daily was also started. His condition started to improve on the $8^{\text {th }}$ day of admission and BiPAP support was also reduced to minimal. On the $12^{\text {th }}$ day of ICU stay, ABG picture had improved (Fig. 1) and he was weaned off BiPAP support and was shifted to a high $\mathrm{FiO}_{2}$ mask at a flow rate of $15 \mathrm{~L} / \mathrm{min}$. There was a significant improvement in the chest X-ray picture, in addition, D-dimer, CRP, S. ferritin, and IL-6 values had also declined significantly (Table 1) and the dose of methylprednisolone was also gradually tapered.

On the $20^{\text {th }}$ day, the patient was maintaining $\mathrm{SpO}_{2}$ of $94 \%$ on room air with no tachypnoea and was afebrile for 6 days. Repeat RT-PCR report for COVID-19 was negative. He was shifted to ward on the $22^{\text {nd }}$ day, and his $\mathrm{SpO}_{2}$ was maintained at $97 \%$ on room air for the next 10 days.

\section{DISCUSSION}

Sarcoidosis is defined as a chronic disease characterized by enlarged lymph nodes and widespread granulomas, which become calcified and cause permanent damage to the lungs [3]. About $2 \%$ of patients with COVID-19 have concomitant pulmonary disease, which can worsen the outcome [4]. The Centre for Disease Control reported that patients with chronic lung disease or moderate to severe asthma are at a higher risk for COVID-19 [5]. The risk of COVID-19related mortality is significantly related to hyperglycemia in people

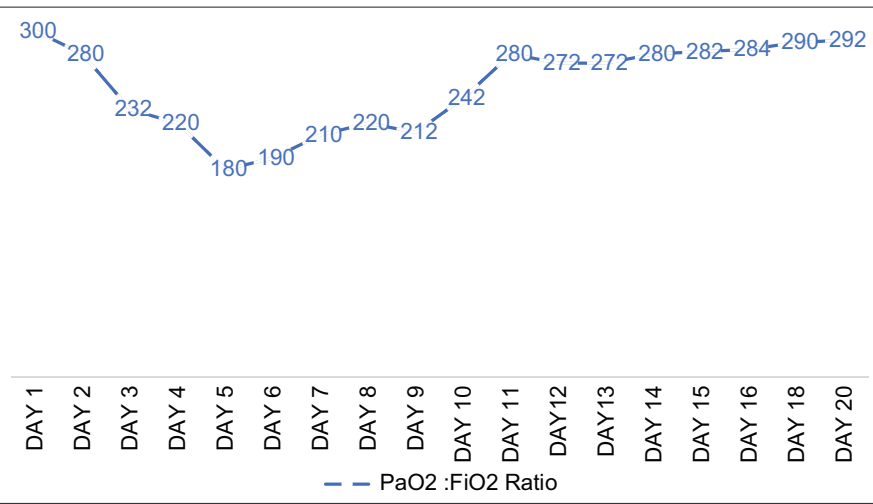

Figure 1: Patients clinical journey in intensive care unit: $\mathrm{PaO2}: \mathrm{FiO} 2$ ratio

Table 1: Trend of D-dimer, C-reactive protein, S. ferritin, and interleukin-6 levels over intensive care unit stay

\begin{tabular}{lcccc}
\hline $\begin{array}{l}\text { Intensive } \\
\text { care unit stay }\end{array}$ & $\begin{array}{c}\text { D-dimer } \\
(\mathbf{n g} / \mathbf{m L})\end{array}$ & $\begin{array}{c}\text { C-reactive } \\
\text { protein }(\mathbf{m g} / \mathbf{d L})\end{array}$ & $\begin{array}{c}\text { S. ferritin } \\
(\mathbf{n g} / \mathbf{m L})\end{array}$ & $\begin{array}{c}\text { Interleukin-6 } \\
(\mathbf{p g} / \mathbf{m L})\end{array}$ \\
\hline Day 1 & 947 & 72.0 & - & - \\
Day 5 & 1227 & 110.0 & 256 & 35.7 \\
Day 8 & 1180 & 44 & - & - \\
Day 12 & 610 & 21 & 112 & 10.2 \\
Day 15 & 512 & 18 & & \\
Day 18 & 487 & 7 & 72 & 6.4 \\
\hline
\end{tabular}

with diabetes as it can impair host defenses, and poor glycemic control has been associated with infections [3].

The management of sarcoidosis during this pandemic poses many challenges. Sarcoidosis patients who cohabitated with COVID-19-infected individuals, worked in health care, had pulmonary or neurologic sarcoidosis, or were treated with rituximab had an increased risk for COVID-19 infection [6]. On a contrary, a case series suggests that African-American patients with chronic sarcoidosis treated with disease-modifying anti-rheumatic drugs or anti-tumor necrosis factor therapy do not seem to be at increased risk of respiratory or life-threatening complications from SARS-CoV-2 compared with the general population, although at the present time, it is suggested to maintain a high level of vigilance and strict follow-up in these patients [7]. This poses a need for an adjustment of the immunosuppressive regimen of the patient with sarcoidosis depending on the stability of the disease and consequences of disease reactivation [8]. A recent article based on the similarity of COVID-19 and sarcoidosis, discusses a combination of the therapeutic strategy of the tetanus-diphtheria vaccine and dual renin-angiotensin system inhibition, with hydroxychloroquine and antiviral agents as a treatment modality [9]. A series of four high-risk, symptomatic, COVID- $19^{+}$patients, with known pulmonary disease, treated with doxycycline showed subsequent rapid clinical improvement [10].

Remdesivir is a 1'-cyano-substituted adenosine C-nucleotide ribose analog that inhibits the proliferation of virus by targeting the RNA polymerase and its antiviral activity [11]. Remdesivir mainly delays the termination of new viral RNA strands. Other pathogenic RNA viruses including Filoviridae, Paramyxoviridae, 
Pneumoviridae, and Orthocoronaviridae can also be inhibited by remdesivir, suggesting its wide range of potential applications [12]. The US Food and Drug Administration had approved the use of plasma from recovered patients to treat people who are critically ill with COVID-19 [13].

Baricitinib, another inhibitor of cytokine release, seems an interesting anti-inflammatory drug. It is a Janus kinase inhibitor (anti-JAK) licensed for the treatment of rheumatoid arthritis with good efficacy and safety records [14]. Moreover, it seems to have anti-viral effects by its affinity for AP2-associated protein AAK1, reducing SARS-CoV-2 endocytosis [15].

In this case report, our patient who was a known case of Stage 4 pulmonary sarcoidosis and type 2 diabetes mellitus was admitted in the ICU with a diagnosis of bilateral pneumonitis, severe acute respiratory illness with COVID-19 positive. The patient had severe hypoxia on the $5^{\text {th }}$ day of admission and was administered injection remdesivir for 10 days and tablet baricitinib $4 \mathrm{mg}$ OD for 2 weeks. He showed significant clinical improvement with a consistent decline in inflammatory marker values after treatment and also, there was a gradual de-escalation of oxygen therapy.

\section{CONCLUSION}

Injection remdesivir along with a multimodal approach including tablet baricitinib, convalescent plasma transfusion, insulin infusion, graded oxygen therapy, prone positioning, steroid, and anticoagulants can be considered as a potential modality of treatment in patients of Asian origin with severe COVID-19 infection associated with sarcoidosis and type 2 diabetes mellitus, although future multicentric randomized control trials are needed for the same.

\section{ACKNOWLEDGMENT}

We would such as to acknowledge the efforts of the staff and workers at GTB Hospital for their efforts in treating this patient.

\section{REFERENCES}

1. World Health Organization Coronavirus (COVID-19) Dashboard. Available from: https://www.covid19.who.int/info. [Last accessed on 2021 May 18].
2. Southern BD. Patients with interstitial lung disease and pulmonary sarcoidosis are at high risk for severe illness related to COVID-19. Cleve Clin J Med 2020;2020:1-4.

3. Prasse A. The diagnosis, differential diagnosis, and treatment of sarcoidosis. Dtsch Arztebl Int 2016;113:565-74.

4. The Lancet Diabetes Endocrinology. COVID-19 and diabetes: A co-conspiracy? Lancet Diabetes Endocrinol 2020;8:801.

5. CDC People Who Are at Higher Risk for Severe Illness; 2020. Available from: http://www.cdc.gov/coronavirus/2019-ncov/need-extra-precautions/ people-at-higher-risk.html. [Last accessed on 2020 Dec 20].

6. Baughman RP, Lower EE, Buchanan M, Rottoli P, Drent M, Sellares J, et al. Risk and outcome of COVID-19 infection in sarcoidosis patients: Results of a self-reporting questionnaire. Sarcoidosis Vasc Diffuse Lung Dis 2020;37:e2020009.

7. Manansala M, Ascoli C, Alburquerque AG, Perkins D, Mirsaedi M, Finn P, et al. Case series: COVID-19 in African American patients with sarcoidosis. Front Med (Lausanne) 2020;7:588527.

8. Sweiss NJ, Korsten P, Syed HJ, Syed A, Baughman RP, Ye AM, et al. When the game changes: Guidance to adjust sarcoidosis management during the coronavirus disease 2019 pandemic. Chest 2020;158:892-5.

9. Ozbalci D. A tale of two diseases: Sarcoidosis, COVID-19 and new therapeutic options with dual RAS inhibition and tetanus-diphtheria vaccine. Med Hypotheses 2021;152:110619.

10. Yates PA, Newman SA, Oshry LJ, Glassman RH, Leone AM, Reichel E. Doxycycline treatment of high-risk COVID-19-positive patients with comorbid pulmonary disease. Ther Adv Respir Dis 2020.

11. Tchesnokov EP, Raeisimakiani P, Ngure M, Marchant D, Gotte M. Recombinant RNA-dependent RNA polymerase complex of Ebola virus. Sci Rep 2018;8:3970.

12. Brown AJ, Won JJ, Graham RL, Dinnon KH $3^{\text {rd }}$, Sims AC, Feng JY, et al. Broad spectrum antiviral remdesivir inhibits human endemic and zoonotic delta coronaviruses with a highly divergent RNA dependent RNA polymerase. Antivir Res 2019;169:104541.

13. Xiao Y, Xu H, Guo W, Zhao Y, Luo Y, Wang M, et al. Update on treatment and preventive interventions against COVID-19: An overview of potential pharmacological agents and vaccines. Mol Biomed 2020;1:16.

14. Bechman K, Subesinghe S, Norton S. A systematic review and meta-analysis of infection risk with small molecule JAK inhibitors in rheumatoid arthritis. Rheumatology 2019;58:1755-66.

15. Richardson P, Griffin I, Tucker C. Baricitinib as potential treatment for 2019-nCoV acute respiratory disease. Lancet 2020;395:e30-1.

Funding: None; Conflicts of Interest: None Stated.

How to cite this article: Bajaj M, Saxena AK, Choudhary S, Jain S. Solicitous use of injection remdesivir, tablet baricitinib, and plasma therapy for severe COVID-19 patient associated with Stage 4 sarcoidosis and type 2 diabetes mellitus: A case report. Indian J Case Reports. 2021;7(7):307-309. 